\section{E-LOGOS}

ELECTRONIC JOURNAL FOR PHILOSOPHY ISSN 1211-0442

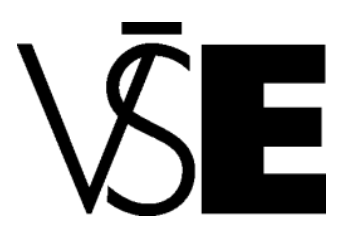

University of Economics Prague

\title{
Občanská společnost z pohledu pluralisty
}

Marek Loužek

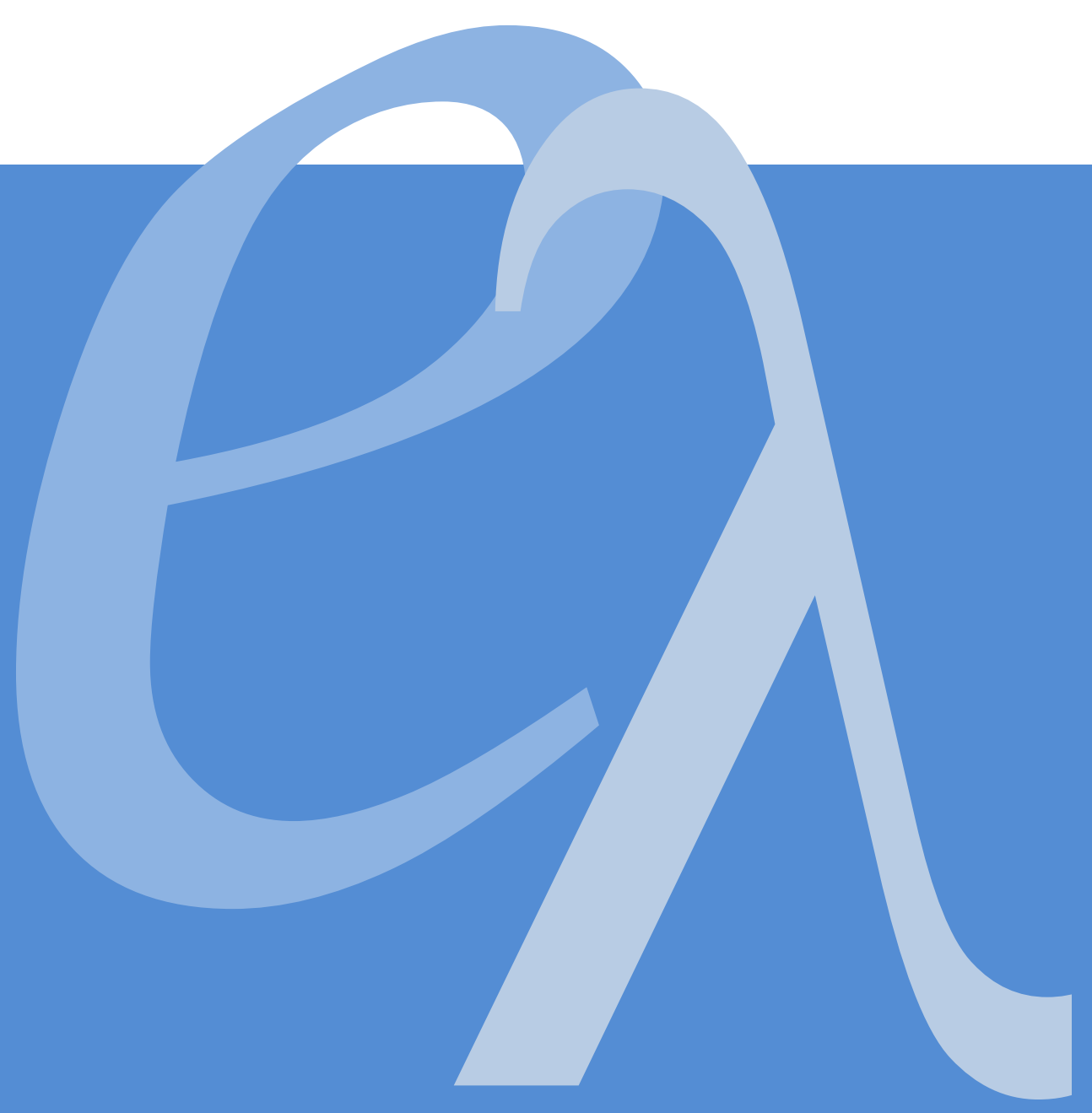




\begin{abstract}
The paper aims to put the civil society in the context of political philosophy and to explain it from a pluralistic perspective. The first part discusses the classical concept of the civil society. The second part examines the civil society during and after the era of Communism. The third part analyses the dispute between corporativism and pluralism. The fourth part distinguishes between political power and influence. The fifth part highlights the roles of political parties. The sixth part points out the suspicious nature of universal moral claims.
\end{abstract}

Keywords: civil society, pluralism, corporativism.

\title{
Abstrakt
}

Cílem stati je zasadit občanskou společnost do kontextu politické filozofie a vysvětlit ji z pluralistického pohledu. První část diskutuje klasické pojetí občanské společnosti. Druhá část zkoumá občanskou společnost $\mathrm{v}$ době komunismu a po něm. Třetí část analyzuje spor mezi korporativismem a pluralismem. Čtvrtá část odlišuje politickou moc a vliv. Pátá část vyzdvihuje roli politických stran. Šestá část upozorňuje na podezřelost univerzálních mravních nároků.

Klíčová slova: občanská společnost, pluralismus, korporativismus. 
Pojem "občanská společnost" se stal běžnou součástí slovníku českých intelektuáli̊. V průběhu uplynulých dvaceti let jsme mnohokrát slyšeli, že občanská společnost je "nerozvinutá", že část politiků málo naslouchá hlasu občanské společnosti, že si občanská společnost přeje A a nepřeje B. Existuje vůbec jednotný hlas "občanské společnosti“? Je koncept občanské společnosti teoreticky ospravedlnitelný? Jakou má oporu ve filozofické tradici? Je pravda, že čeští politici rozvoj občanské společnosti blokují?

Cílem stati je zasadit občanskou společnost do kontextu politické filozofie a vysvětlit ji z pluralistického pohledu. První část diskutuje klasické pojetí občanské společnosti. Druhá část zkoumá občanskou společnost v době komunismu a po něm. Třetí část analyzuje spor mezi korporativismem a pluralismem. Čtvrtá část odlišuje politickou moc a vliv. Pátá část vyzdvihuje roli politických stran. Šestá část upozorňuje na podezřelost univerzálních mravních nároků.

\section{Klasické pojetí občanské společnosti}

Některá slova slýcháme tak často a běžně, že si ani nestačíme uvědomit jejich původ. Používání slov není samožrejmé, pojem musel někde vzniknout, v průběhu doby se mírně proměňoval jeho obsah či kontext. Sem patři termíny jako tržní ekonomika, právní stát, liberální demokracie, ale i občanská společnost (Kumar 1993). Občanská společnost patří k nejmlhavějším i nejrozpornějším pojmům politické filozofie.

Ačkoli je pojem občanské společnosti jednoduchý, historická představa s ním spojená je spletitá a komplikovaná. Když si uvědomíme, že její kořeny tkví v hegelovsko-marxistické metafyzice, která není právě vzorem srozumitelnosti, není to př́liš překvapivé. Jestliže tedy máme ustavit propojení občanské společnosti s prehistorií koncepce, nevyhneme se troše úklidu (Gellner 1997).

V klasickém pojetí byla „občanská společnost" synonymem pro "politickou společnost“. Když John Locke hovořil o "civil government“, Immanuel Kant o „bürgerliche Gesellschaft“ či Jean Jacques Rousseau o „état civil“, mínili tím stát, který ohraničoval - podobně jako v řecké polis - oblast politiky. Občanská společnost byla arénou, kde se setkávali politicky aktivní občané (Ehrenberg 1999).

Převrat v uvažování přinesla druhá polovina 18. století. Ve spisech Thomase Paina, Adama Smithe či Adama Fergusona začíná být společnost chápána odděleně od státu - jako autonomní sféra, která se řídí svými vlastními principy a zákony. V klasickém Fergusonově díle „Essay on the History of Civil Society“ ([1767] 1995) se jako červená nit táhne právě odlišení státu a občanské společnosti.

Jedním z kontrastů v pojmu občanská společnost je kontrast mezi ekonomickými a společenskými činnostmi na jedné straně a centralizovaným udržováním pořádku na 
straně druhé. Jestliže stát porazí a zničí nebo si podrobí občanskou společnost, $\mathrm{v}$ širším pluralitním světě, v němž národní bohatství a jeho růst hraje klíčovou úlohu, na chybu doplatí společnost jako celek, a nakonec musí napravit a zvrátit toto katastrofické vítězství (Ferguson 1995).

Občanská společnost je založena na oddělení politického zřízení od hospodářského a společenského života (tj. od společenského rezidua, které zůstane po odečtení státu), ale to je kombinovaná s absencí nadvlády držitelů moci nad společenským životem. Tato situace je tak podivná a stěží představitelná v tradičním agrárním světě, že Adamu Fergusonovi připadala překvapivá a riskantní (Gellner 1997).

Fergusonovo vysvětlení vzniku moderního státu je důvtipné: monarcha si ve svazku s lidem podřídí feudální panství, osvobodí lid zpod poddanství pánů a podporuje vykonávání obchodnických a výnosných dovedností. To může někdy korunu posílit, ale může se to obrátit i proti ní a vést $\mathrm{k}$ něčemu novému $\mathrm{v}$ dějinách lidstva - monarchii smíchané s republikou, rozsáhlým územím po dlouhou dobu spravovaným bez vojenské síly (Ferguson 1995).

V podobné linii pokračuje Georg Friedrich Wilhelm Hegel. V jeho „Základech filozofie práva“ ([1821] 1992) je občanská společnost chápána jako sféra etického života nacházející se mezi rodinou a státem. Občanská společnost získává i jistý ekonomický nádech: znamená volnou hru tržních sil a sledování vlastního zájmu jednotlivců, což jsou činnosti nezávislé na státu (Encarnación 2006).

Od Hegela přebírá termín Karel Marx, který občanskou společnost chápe jako oblast soukromého vlastnictví a tržních vztahů. Marx dospívá k závěru, že „občanská společnost“ jako označení pro společnost či ekonomiku oddělenou od státu je nadbytečné, nebot' bohatě stačí prozaická dichotomie stát - společnost. Díky Marxovi se německý termín „bürgerliche Gesellschaft" překládá nejen jako „občanská společnost“, ale někdy i jako „,buržoazní společnost“ (Niemi 2011).

Občanskou společnost nebo společnost, která občanskou společnost obsahuje (v užším smyslu), odlišuje od jiných to, že není jasné, kdo je vládcem. Občanská společnost může státu oponovat a kontrolovat ho. Neleží před ním na lopatkách. Podle jejího nejvlivnějšího kritika Karla Marxe je vládcem občanská společnost sama a moc státu, či dokonce jeho nezávislost, je pouhá fasáda a klam (Howell, Pearce 2001).

Nejen myslitelé ovlivnění Marxem ale i jeho odpůrci viděli stále méně důvodů pro udržení konceptu občanské společnosti. Ještě Alexis de Tocqueville se pokusil oživit občanskou společnost, když jí pojmenoval politické vzdělávání, které má předcházet aktivní politické dráze. Odumření pojmu se však již nedalo zabránit. Ve druhé 
polovině 19. století se užívání slova „občanská společnost“ spíše upustilo (Seligman 1992).

Vzkřrišení „občanské společnosti“ (civil society) provedl ve dvacátém století italský marxista Antonio Gramsci. V díle „Dopisy z vězeni“ (1949) odděluje občanskou společnost od ekonomiky a umist'uje ji (narozdíl od Hegela a Marxe) dovnitř státu. Občanská společnost je vnímána jako součást státu, která neslouží k vynucování formálních pravidel, nýbrž k vytváření konsensu - v praxi „kulturní politiky“ (Rucht 2011).

\section{Občanská společnost $\mathrm{v}$ éře komunismu a po něm}

Renesanci prožívala „občanská společnost“ ve střední a východní Evropě v 70. a 80. letech. Disidenti využívali koncept „občanské společnosti“ jako účinné zbraně proti komunistickému systému. Solidarita v Polsku či disidentské skupiny v Československu vytvořily specifický model „nepolitické“ opozice, který se snažil vyhnout sebevražedné konfrontaci se státem a namísto toho vytvářel tzv. „paralelní polis" (Havel 1990).

Disidenti se k občanské společnosti obrátili, nebot' velmi stručně a sugestivně nesla to, co jim nejvíce chybělo a po čem nejvíce toužili. Touha po občanské společnosti se zrodila ze společenských podmínek východní Evropy a sovětského světa. Občanská společnost je hroznem sdružení a institucí, které jsou dost silné, aby zabránily tyranii, ale do nichž je nicméně možno svobodně vstoupit a zase je opustit, nejsou vnuceny narozením či udržovány nějakým děsivým rituálem (Gellner 1997).

Občanská společnost jako obrana proti svévoli autoritativního režimu sehrála pozitivní úlohu. Mohla si dovolit tvářit se "nepoliticky“, protože všichni měli společného tichého nepř́tele - komunistickou stranu s jejím mocenským monopolem. Po roce 1989 však nastal problém, nebot' politicky aktivní občané se „rozutekli“ do různých stran a straniček a původní hřejivá jednota "občanské společnosti“ vychladla (Dahrendorf 1997).

Disidenti, kteří o rozvoj občanské společnosti vždy pečovali, byli náhle postaveni před úkol obhájit tento koncept i v demokratických poměrech. Vcelku se jim podařilo prosadit ve veřejnosti novou definici "občanské společnosti“ jako množiny nadací, spolků, univerzit, církví, odborů, které působí mezi občanem a státem, a jež jsou nezbytné pro fungování zdravé společnosti (Müller 2002).

Kdyby zůstalo u této nevinné definice, bylo by všechno v pořádku. Ve filozofické tradici Václava Havla (1990) však byl pojem "občanská společnost" navíc svázán s konceptem tzv. „nepolitické politiky“. Havel byl vždy nedůvěřivý k politickým stranám, kritizoval západní kapitalismus a občanskou společnost chápal svým 
způsobem jako „konkurenta“ vůči "přízemni“" zastupitelské demokracii, která povede přes existenciální revoluci k éře autentické svobody (Myant 2005).

"Občanská společnost" v ČR se tak začala stále intenzivněji vymezovat proti standardním politickým procedurám. Za posledních dvacet let se několikrát vynořily občanské iniciativy a hnutí, které se snažily vytvořit „novou“ politiku, protože ta „klasická", „stranická“ a „ideologická“ se podle jejich názoru přežila. Občanská společnost se v praxi chtěla stát náhražkou, nikoli doplňkem pluralitní demokracie (Klaus 2002).

Z tohoto pohledu představuje komplex myšlenek spojených s koncepcí občanské společnosti něco, co je nepravé a nadbytečné (Gellner 1997). Harmonický společenský rád, osvobozený od vykořist'ování i od útisku, je žádoucí. Návod k jeho ustanovení je $\mathrm{k}$ dispozici - svoboda a demokracie. Jeho realizace je na pořadu dějin a jeho př́chod je zajištěn vnitřní logikou událostí a železnou vưlí kvazináboženského řádu zasvěceného jeho uskutečnění.

Zpochybnění pojmu občanská společnost by se mezi částí našich intelektuálů rovnalo takřka rouhání. Připomeňme, že anglické slovičko "civil“ neznamená jen "občanský" - ale v jiném významu - také „zdvořilý“ či „civilizovaný" (Fajmon 2008). Člověk, který se o občanské společnosti vyjadřuje skepticky, je proto zákonitě pokládán za kacíře. Přesto - anebo právě proto - se zdá, že naděje, které jsou do tohoto konceptu vkládány, jsou trochu přehnané.

Cílem další části stati je vyslovit o občanské společnosti čtyři závažné teze: 1 . občanská společnost je svou podstatou pluralitní, nikoli homogenní, 2. občanská společnost by měla respektovat rozdíl mezi politickou mocí a vlivem, 3. občanská společnost se může stát doplňkem, nikoli však náhražkou pluralitní demokracie, 4 . občanská společnost nestojí na morálním piedestalu - ani vůči občanům jako jednotlivcům, ani vůči demokraticky zvoleným reprezentantům.

\section{Spor mezi korporativismem a pluralismem}

Pokud už pojem občanská společnost akceptujeme, zjistíme, že občanská společnost je svou podstatou pluralitní, tj. vnitřně heterogenní (Brokl 2002). Občanská společnost není jednotný celek, kde by všichni měli stejné názory, preference a zájmy. Odlišné názory, preference a zájmy naopak mezi sebou soutěží, konkurují si. Neexistuje žádný zájem či názor "občanské společnosti“ jako celku, existuje jen zájem či názor konkrétních členů občanské společnosti (jednotlivců, spolků nebo sdružení), o jehož správnosti musí tito lidé přesvědčit ostatní.

„Občanskou společnost" ve smyslu tisíce občanských sdružení, spolků a nadací u nás nepochybně máme (Vajdová 2005, Guasti 2005). Je to občanská společnost mimořádně pestrá, přebohatě strukturovaná a přináší hluboké uspokojení všem, 
kteří se jí aktivně účastní. Každý občan je členem nějaké obce, církve, univerzity, odborového svazu apod. Stížnost, že občanská společnost je u nás málo rozvinutá, zní v tomto kontextu opravdu podivně.

Otázka je jiná. Zní: 1. zda a nakolik má stát „občanskou společnost“ nějak podporovat, chránit, ekonomicky zvýhodňovat některé její součásti - ve formě dotací, daňových úlev apod. a 2. zda má vybrané „reprezentanty“ občanské společnosti „vtáhnout" do procesu kolektivního rozhodování, pokud se neúčastnili demokratických voleb (Brennan, Petit 2004).

Toto dilema politologové důvěrně znají z debaty mezi korporativismem a pluralismem. Korporativismus představuje společensko-ekonomické uspořádání, kdy existuje omezený počet privilegovaných sdružení, které spolurozhodují o politice státu. Stát vybrané představitele „společnosti“ vtahuje do kolektivního rozhodování na základě jejich "vzdělání", "přirozené autority“, "stavovského zařazení" či „příslušnosti k elitě“. Občanské spolky a sdružení se zavazují podporovat politiku státu a ten jim na oplátku poskytuje různé ekonomické či sociální výhody (Madison 2003).

Př́kladem korporativistického modelu může být italský fašismus v době Mussoliniho. Státní korporativismus znamenal podřízenost zájmových organizací autoritářské vládě a možnosti státního přinucení. V demokratickém provedení se korporativismus uplatnil v poválečném Rakousku, kde bylo zavedeno povinné členství v profesních komorách, odborových svazech a dalších sdruženích, které spoluurčovaly (a dodnes spoluurčují) politiku státu (Windschuttle 1999).

Je pozoruhodné, že Mussolini vytýkal zastupitelské demokracii podobné věci, které můžeme občas číst $\mathrm{v}$ našem tisku z pera některých politiků i intelektuálo̊, kteří v dobrém úmyslu, ale bez znalosti těchto tabuizovaných pramenů, se snaží zdravým selským rozumem zastupitelskou demokracii učinit demokratičtější, zejména oslabením role politických stran, nebo přímějším, méně agregovaným zastupováním zájmů v parlamentu (Brokl 1997).

Pluralismus je naopak založen na konkurenci velkého počtu dobrovolných zájmových sdružení a spolků, z nichž žádný nemá privilegované postavení a všechny soutěží s ostatními o členy, zdroje a př́istup k politice. Politická rozhodnutí může "občanská společnost" ovlivňovat, nemůže však o nich spolurozhodovat. Žádný jednotný hlas „občanské společnosti“ neexistuje, nebot’ sdružení A, B, C či D jsou heterogenní a prosazují odlišné zájmy a představy o „optimální“ podobě společnosti (Seligman 1992).

Pluralisté argumentují, že společenské zájmy si vzájemně konkurují v získání a udržení politické moci a vlivu. Konkurující zájmy se vzájemně kontrolují a omezují navzájem svou moc. Tím pluralitní zájmová konkurence vede ke společenské 
rovnováze s optimálním uplatněním společenských zájmů v politickém rozhodování. Proto je pluralismus zastupitelské demokracie základním kamenem legitimity a racionality demokratické vlády (Brokl 1997).

Příklon ke korporativismu či pluralismu je legitimní, zastánci obou koncepcí by to však měli jasně přiznat. Mávat občanskou společností a neříci, $k$ jakému z obou přístupů se propagátor hlásí, je neúplné a neseriózní. Pluralistický prrístup je přitom v argumentační výhodě, protože občanská společnost skutečně nemluví „,jedním hlasem“, je vysoce segmentovaná a zájmově i názorově rozrůzněná. Politické spektrum je spíše odrazem přirozené plurality občanské společnosti, než její umělou protiváhou nebo dokonce soupeřem (Pabst, Scazzieri 2012).

Korporace, které nejsou voleny, tj. legitimovány všeobecnými volbami jako politické strany, se snaží v korporativistickém modelu působit ve sfére politické a rozhodovací moci. Kdyby toho dosáhly, byl by narušen základní princip demokratického uspořádání politické i státní moci zastupitelské parlamentní demokracie, princip reprezentace a rozhodování. Delegáti korporací v parlamentu, např. odborů, místo poslanců zastupujících všechen lid, by již reprezentovali jiný režim než parlamentní zastupitelskou demokracii (Brokl 1997).

Aby se dílčí zájem mohl uplatnit v pluralitě konkurujících si zájmů demokratické společnosti, musí vstoupit do politického procesu, vněmž je artikulován, manifestován, sdružován (agregován) s obdobnými zájmy, filtrován a selektován různými stupni voleb na různých úrovních reprezentován a uspokojován (Brokl 2002). Korporativní zprostředkování zájmů je antitezí liberální plurality.

\section{Odlišení politické moci a vlivu}

Členové "občanské společnosti“ by měli respektovat rozdíl mezi politickou mocí a vlivem. Politickou moc drží v rukou subjekty, které se zúčastnily regulérních demokratických voleb, získaly parlamentní či vládní křesla a prosazují politiku, kterou považují za správnou. V západní demokracii se nejschopnějšími dobyvateli moci ukázaly být politické strany, jež disponují více či méně pevnou vnitřní strukturou a pro něž je podíl na moci jedním z hlavních cílů. Nic však nebrání jedincům či nezávislým hnutím, aby se o politickou moc ucházely rovněž (Corry 2006).

Politický vliv znamená schopnost jednotlivců nebo skupin oslovovat veřejnost a přesvědčovat ji o správnosti svých názorů. V každé demokracii působí tisíce občanských seskupení, která nemají žádnou politickou moc (ve smyslu pravomoci provádět ústavní rozhodnutí), ale mají obrovský vliv. K politickým otázkám se běžně vyjadřují církve, odbory, think tanky, profesní či zájmová sdružení. Držitelé politické moci - především politické strany - jim naslouchají a komunikují s nimi (Hrubec 2005). 
Politický vliv si nelze vyvzdorovat žádnou kolektivní akcí či peticí. Politický vliv vzniká přrirozenou autoritou a trpělivou prací v rámci standardních mechanismů. Jednotliví „členové“ občanské společnosti vyslovují chytré názory v médiích, kážou v kostelích, přednášejí na univerzitách a přicházejí s nápady a myšlenkami, které mohou profesionální politici využít ve své práci. Tak vzniká vliv - politický vliv (Shaw 1994).

Pokud není intelektuál spokojen se svým politickým vlivem, má v zásadě dvě možnosti: 1. může publikovat ještě kvalitnější články, vystupovat ještě provokativněji v televizi, ještě emocionálněji kázat, ještě přesvědčivěji přednášet - prostě lépe veřejně vystupovat než dosud. Nebo 2. může vstoupit do některé z existujících stran, získat politickou moc a prosazovat vlastní názory v aktivní politice (Amoore 2004).

Je pochopitelné, když někteří intelektuálové mají pocit, že je společnost nedoceňuje, případně mají menší politický vliv, než by si přáli. To je ostatně vlastnost každého člověka, nejen intelektuála (Hefner 1998). Každý si přeje, aby jeho vliv ve společnosti byl co největší, a každý má sklon si namlouvat, že by si zasloužil víc vážnosti, než mu ostatní poskytují. Zní to krutě, ale neexistuje jiná cesta, než houževnatě pracovat a trpělivě si jméno a intelektuální vážnost budovat. Petice za nikoho tvrdou práci neodvedou.

Když si např. Impuls '99 jako jeden z (mnoha) subjektů „občanské společnosti“ stěžoval, že jej politici berou málo vážně, měl by se zamyslet především sám nad sebou. Kdyby místo vznešených frází první iniciátor sepsal návrh na sociální reformu, druhý zanalyzoval volební systém, třetí vymyslel chytrý zpơsob financování zdravotnictví a čtvrtý rozpracoval ekologii, zvýšili by svůj politický vliv tisíckrát víc než jednou mlhavou peticí.

Současní angažovaní stoupenci občanské společnosti uvízli v zajetí disidentských představ o občanské společnosti a její spasitelné role, díky níž vede zbytek společnosti a obdarovává ji svobodou, která dojde vyvrcholení v přímé občanské participaci bez zprostředkování politickými stranami (Brokl 2002). Tím, že nedávají prostor politice jako zprostředkování zájmů, nedávají prostor ani demokracii.

\section{Role politických stran}

„Občanská společnost“ nikdy nemůže nahradit klasickou demokratickou politiku založenou na soutěži zájmů, ideologií a politických stran. Občanská společnost se může stát pouze doplňkem, nikoli náhražkou pluralitní demokracie (Layton 2006).

Z premisy, že občanská společnost je svou podstatou pluralitní, plynou závažné konsekvence. Protože se představy jednotlivých občanů o správné podobě společnosti liší, je logické, že existují alternativní hodnoty, programy či ideologie, které mezi sebou na politickém trhu soutěží. Aby mohla nějaká skupina prosadit 
politický program (tj. nechce se spokojit s pouhým politickým vlivem), musí získat politickou moc.

Instituce, které v západních demokraciích usilují o politickou moc, aby realizovaly svůj program, jsou politické strany (Novák 1997). Politické strany působí celostátně a obvykle na všech úrovních státního uspořádání, vyjadřují společenské zájmy, usilují o získání státní moci a obsazení úřadů. Strany usilující o voliče jsou programové, mají priority problémů a cílů, prostředky kjejich dosahování a mají obvykle formulované cíle v čase (Brokl 1997).

Pro politology vypadají tato slova jako triviální konstatování (Cohen, Arato 1992). Bohužel v uplynulých dvaceti letech vyrostla řada iniciativ, které dávaly najevo jakési obecné znechucení z politiky a politiků, stěžovaly si, že politici neřeší „reálné problémy země“, zabývají se jen „mocenskými hrátkami“, že jsou „příliš ideologičtí a málo věcní", v horším případě že jsou přímo cyničtí, velikáští a arogantní.

Zdá se, že tato kritika je př́liš paušální a může - aniž by to iniciátoři zamýšleli podkopat důvěru v samotný demokratický režim. Kdyby autoři podobných petic klidně a věcně kritizovali politické poměry, nepochybně by došli k závěru, že problém je daleko složitější, než jak jej prezentují. Poměr mezi pravicí a levicí ve volebních preferencích zůstává již několik let konstantní, zvýšil se však počet stran, které si je mezi sebou dělí.

Je omylem vnímat občanskou společnost jako demokracii samu, která je stavěna proti politickým stranám, jako něco, co by je vlastně mělo nahradit. Role občanské společnosti je dezinterpretována jako nedefinované permanentní působení v politice, pod níž se rozumí spíše politika velká než malá, navíc při mediálním zpochybňování voleb uskutečňovaných pouze jednou za čtyři roky (McLaverty 2002).

Je překvapivé, jak rychle se začal šířit staronový mýtus o věcných a neideologických řešeních. Některé iniciativy přišly s tvrzením, že politici málo naslouchají odborníkům a že jsou přiliš v zajetí ideologických klišé. Žádné kolektivní rozhodování však nelze provádět bez hodnot, bez programu, bez ideologie. Víra, že společenské a ekonomické problémy lze přenechat „nezávislým expertům”, kteří budou objektivně a nestranně rozhodovat, je největší omyl, jakého se intelektuál může dopustit (Madison 2003).

Tváří v tvář utopickým iniciativám je třeba občanům stále připomínat, že jiná politika než „politická“ být nemůže, že zájmovost, stranickost a ideologičnost - byt” mohou na první pohled vypadat „přízemně“ a „cynicky“ - jsou esenciální součástí každé demokratické politiky. Občanská společnost nemůže demokratickou politiku nahradit, může se nanejvýš stát jejím doplňkem (Keane 2003).

Někteří politikové a téměř všechna média vidí občanskou společnost tam, kde prokazatelně není, např. v politice, parlamentu, na náměstích velkoměst, a nevidí ji 
tam, kde přrirozeně vzniká (Alexander 1997, Brokl 2002). Zatímco svět občanskou společnost ztotožňuje s nevládními organizacemi, média a politikové ji neustále ztotožňují s efemérními společenskými a politickými hnutími, makropolitickými nátlakovými akcemi a pouličními demonstracemi, nikoli s drobnou prací v místech, kde občané konkrétně žijí (Otero 2004).

\section{Podezřelost univerzálních morálních nároků}

Zástupci jednotlivých občanských sdružení a iniciativ by měli odolat pokušení mluvit za celou "občanskou společnost“, předstírat, že právě v nich se občanská společnost „probouzi““ a tryská zázračnou životadárnou sílu (Rohrbacher 2008).

Protože pluralisté vnímají společnost jako názorově i zájmově diferencovanou, neexistují pro ně žádné privilegované spolky či sdružení. Občanské a politické iniciativy si konkurují, soupeří spolu o členy, zdroje a politický vliv. Představa, že kdesi „ve zlatém středu“ občanské společnosti existuje skupina, která vyzařuje morální hodnoty a moudrým zrakem dohlíží na zdravý vývoj celé občanské společnosti, by možná byla přijatelná $\mathrm{v}$ platónské polis, ale k realitě v západní demokracii na počátku 21. století má hodně daleko (Howell, Pearce 2001).

Debatu o morálních hodnotách politická filozofie důvěrně zná ze sporu tzv. komunitarismu s klasickým liberalismem. Komunitariánství je vnitřně rozrůzněný proud, pro nějž je typický důraz na komunitu a univerzální morální hodnoty, které by jednotlivci i společnost měli respektovat. Klasičtí liberálové jsou možná více relativističtí, nebot' nedůvěřují vyhlašování spásných hodnot či univerzálních mravních cílů (Ehrenberg 1999).

Co je však podstatné: i kdybychom připustili, že univerzální morální hodnoty existují, stále by přetrvávala otázka, které z občanských sdružení či iniciativ je ztělesňuje (Papakostas 2011). Debata, zda univerzální mravní hodnoty přináší Impuls, Nadační fond proti korupci, Centrum pro ekonomiku a politiku či jiná organizace, je možná zajímavá, přesto bych se na tak tenký led neodvážil vstoupit.

Bylo by velmi nešt'astné, kdyby se jedno sdružení či spolek pasovalo na „zlatý střed“ občanské společnosti, jehož názorům a poselství by měli ostatní povinně naslouchat (Green 2005). Sliby vnitřní slušnosti a všeobecné morální apely jsou esteticky působivé, ale reálná politika je přece jen o něčem jiném: o kompromisech, zprostředkování zájmů a hledání průniků programů odlišných politických seskupení.

Problém občanské společnosti je v českém novinářském diskurzu chápána zjednodušeně jako problém samotné demokracie, která se obejde bez politických stran a jíž politické strany spíše škodí (Brokl 2002). Všechny snahy o systémové 
vylepšení tohoto mechanismu oslabením nebo vyřazením politických stran vedly ve 20. století $\mathrm{k}$ nastolení některé formy totalitarismu - levého nebo pravého.

\section{Závěr}

Existují dva modely demokratického zprostředkování zájmů. Pluralitní model je založený na individuálním principu občanské rovnosti a svobody, na principu konfliktu zájmů a jejich realizace pomocí svobodného soupeření politických stran. Korporativismus je naopak založen na kolektivním principu př́islušnosti k určitému segmentu populace, na organizovaném harmonizování zájmů pomocí korporací, které delegují zástupce do parlamentu.

Z pluralistického pohledu je občanská společnost heterogenní útvar, který nemluví jedním hlasem ani se jednotně „neprobouzi“" v závislosti na tom, jaká politická strana je zrovna u vlády. $V$ demokratické společnosti mají jednotlivci právo se sdružovat do spolků a iniciativ, at' už politických či nepolitických. Vytvářejí-li však politický tlak, neměli by podléhat následujícím iluzím:

1. iluzi, že mají apriorní morální právo být přímo vtaženi do kolektivního rozhodování, aniž by prošly nejspravedlivějším sítem zastupitelské demokracie svobodnými volbami;

2. iluzi, že politický vliv si lze vyvzdorovat peticemi a že politici jsou povinni naslouchat jejich hlasu, pokud přichází jen s extrémizovanou kritikou a s žádnými pozitivními nápady;

3. iluzi, že klasická politika založená na střetu zájmů, programů a soutěži politických stran se přežila, a že „občanská společnost“" se stane náhražkou (a nikoli doplňkem) pluralitní demokracie;

4. iluzi, že konkrétní spolek či subjekt „občanské společnosti“ má monopol na společenskou pravdu či univerzální morální hodnoty.

Pokud některé iniciativy „občanské společnosti“ podléhají výše uvedeným iluzím, neznamená to ještě, že jsou nelegitimní. Každý má právo hájit korporativistický pohled na svět, snažit se zvýšit politický vliv mlhavými peticemi, věřit, že klasická politika založená na soutěži stran, zájmů a programů se přežila nebo že právě on představuje onen "zlatý střed“ občanské společnosti, kterému ostatní mají povinně naslouchat. Co je však třeba přiznat, je svrchovaně "politický“ a programový charakter každé takové koncepce. Předstírat, že občanská společnost v ČR je nepolitická či dokonce „nadpolitická“ kategorie, by bylo neupřímné.

To, že různí politici naslouchají hlasu různých občanských iniciativ, je přirozené. Stavět celý problém do polohy, že na jedné straně stojí zapálení nadšenci, kteří chtějí rozvíjet občanskou společnost, a na druhé straně jsou zlí politici, kteří jim to nechtějí dovolit, by bylo zavádějící. 


\section{Bibliografie}

Alexander, J.: The Paradoxes of Civil Society: International Sociology 12 (1997), č.2, s. $115-133$.

Amoore, L.: Ambiguities of global civil society: Review of International Studies 30 (2004), č. 1, s. 89-110.

Brennan, G. - Petit, Ph.: The economy of esteem: an essay on civil and political society: Oxford, Oxford University Press 2004.

Brokl, L.: Hledání občanské společnosti: Praha, Národohospodářský ústav Josefa Hlávky 2002.

Brokl, L.: Pluralitní demokracie nebo neokorporativismus? In: Brokl, L. a kol.: Reprezentace zájmů v politickém systému ČR: Praha, SLON 1997, s. 11-97.

Cohen, J. - Arato, A.: Civil Society and Political Theory: London, Verso 1992.

Corry, T. O.: Global Civil Society and Its Discontents: Voluntas 17 (2006), č. 4, s. 302-323.

Dahrendorf, R.: After 1989: morals, revolution and civil society: Basingstoke, Macmillan 1997.

Ehrenberg, J.: Civil society. The critical history of an idea: New York, New York University Press 1999.

Encarnación, O. G.: Civil Society Reconsidered: Comparative Politics 38 (2006), č. 3, s. 357-376.

Fajmon, H.: Občanská společnost. In: Slovníček evropských levicových pojmů: Brno, CDK 2008, s. 83-92.

Ferguson, A.: Essay on the History of Civil Society: Cambridge, Cambridge University Press 1995.

Gellner, E.: Podmínky svobody. Občanská společnost a její rivalové: Brno, CDK 1997.

Gramsci, A.: Dopisy z vězení: Praha, Svoboda 1949.

Green, D. G.: Civil Society: London, Civitas 2005.

Guasti, P.: Civil society and civic participation in the Czech Republic: Praha, Sociologický ústav Akademie věd ČR 2005. 
Havel, V.: O lidskou identitu: Praha, Rozmluvy 1990.

Hefner, R.: Civil Society. Cultural Possibility of a Modern Ideal: Society 35 (1998), č.3, s. 16-27.

Hegel, G. F. W.: Základy filozofie práva: Praha, Academia 1992.

Howell, J. - Pearce, J.: Civil Society and Development. A Critical Exploration: Boulder, Colorado, Lynne Riener 2001.

Hrubec, M. (ed.): Demokracie, veřejnost a občanská společnost: Praha, Filosofia 2005.

Keane, J.: Civil Society. Old Images, New Visions: Cambridge, Cambridge University Press 2003.

Klaus, V.: Liberalismus a občanská společnost. In: Klaus, V.: Občan a obrana jeho státu: Praha, CEP 2002, s. 19-23.

Kumar, K.: Civil Society. An enquiry into the usefulness of an historical term: British Journal of Sociology 44 (1993), s. 374-395.

Layton, R.: Order and anarchy. Civil society, social disorder and war: Cambridge, Cambridge University Press 2006.

Locke, J.: Two Treatises on Government: Cambridge, Cambridge University Press 1988.

Madison, G. B.: The political economy of civil society and human rights: London - New York, Routledge 2003.

McLaverty, P.: Civil Society and Democracy: Contemporary Politics 8 (2002), č. 4, s. 303-318.

Müller, K.: Češi a občanská společnost: Praha, Triton 2002.

Myant, M.: Klaus, Havel and the debate over civil society in the Czech Republic: Journal of Communist Studies and Transitions Politics 21 (2005), č.2, s. 248-267.

Niemi, W. L.: Karl Marx's sociological theory of democracy: civil society and political rights: Social Science Journal 48 (2011), č.1, s.39-51.

Novák, M.: Systémy politických stran: Praha, Sociologické nakladatelství 1997.

Otero, G.: Global Economy, Local Politics. Indigenous Struggles, Civil Society and Democracy: Canadian Journal of Political Science 37 (2004), č.4, s. 329-346. 
Pabst, A. - Scazzieri, R.: The Political Economy of Civil Society: Constitutional Political Economy 23 (2012), č. 4, s. 337-356.

Papakostas, A.: The realization of civil society: Current Sociology 59 (2011), č. 1, s. 5 23.

Rohrbacher, T.: Global civil society. Conceptual questions: Prague, Oeconomica 2008.

Rucht, D.: Civil society and civility in twentieth-century theorising: European Review of History 18 (2011), č. 3, s. 387-407.

Seligman, A.: The idea of civil society: Princeton, Princeton University Press 1992.

Shaw, M.: Civil Society and Global Politics: Millenium 23 (1994), č.3, s.647-667.

Vajdová, T.: An assessment of Czech civil society in 2004: after fifteen years of development: Brno, Academic Press CERM 2005.

Windschuttle, K.: Civil Society and the Academic Left: Quadrant Magazine 43 (1999), č.7-8, s. 25-30. 


\section{E-LOGOS}

ELECTRONIC JOURNAL FOR PHILOSOPHY

Ročník/Year: 2013 (vychází průběžně/ published continuously)

Místo vydání/Place of edition: Praha

ISSN 1211-0442

Vydává/Publisher:

Vysoká škola ekonomická v Praze / University of Economics, Prague

nám. W. Churchilla 4

Czech Republic

13067 Praha 3

IČ: 61384399

Web: http:/ / e-logos.vse.cz

Redakce a technické informace/Editorial staff and technical information:

Miroslav Vacura

vacuram@vse.cz

Redakční rada/Board of editors:

Ladislav Benyovszky (FHS UK Praha, Czech Republic)

Ivan Blecha (FF UP Olomouc, Czech Republic)

Martin Hemelík (VŠP Jihlava, Czech Republic)

Angelo Marocco (Pontifical Athenaeum Regina Apostolorum, Rome, Italy)

Jozef Kelemen (FPF SU Opava, Czech Republic)

Daniel Kroupa (ZU Plzeň, Czech Republic)

Vladimír Kvasnička (FITT STU Bratislava, Slovak Republic)

Jaroslav Novotný (FHS UK Praha, Czech Republic)

Jakub Novotný (VŠP Jihlava, Czech Republic)

Ján Pavlík (editor-in-chief) (VŠE Praha, Czech Republic)

Karel Pstružina (VŠE Praha, Czech Republic)

Miroslav Vacura (executive editor) (VŠE Praha, Czech Republic) 